\title{
Natural polymers in photodynamic therapy and diagnosis
}

\section{Naturalne polimery w terapii i diagnostyce fotodynamicznej}

\author{
Julita Kulbacka ${ }^{A, B, D, F}$, Anna Choromańska ${ }^{B-D, F}$, Zofia Łapińska ${ }^{B-D, F}$, Jolanta Saczko ${ }^{B-D, F}$ \\ Department of Molecular and Cellular Biology, Faculty of Pharmacy, Wroclaw Medical University, Poland \\ A - research concept and design; B - collection and/or assembly of data; C - data analysis and interpretation; \\ $D$ - writing the article; $E$ - critical revision of the article; $F$ - final approval of the article
}

Polymers in Medicine, ISSN 0370-0747 (print), ISSN 2451-2699 (online)

Polim Med. 2021;51(1):33-41

Address for correspondence

Julita Kulbacka

E-mail: Julita.Kulbacka@umw.edu.pl

\section{Funding sources}

None declared

\section{Conflict of interest}

None declared

\section{Received on May 21, 2021}

Reviewed on June 9, 2021

Accepted on June 29, 2021

Published online on July 30, 2021

Cite as

Kulbacka J, Choromańska A, Łapińska Z, Saczko J. Natural polymers in photodynamic therapy and diagnosis. Polim Med. 2021;51(1):33-41. doi:10.17219/pim/139587

DOI

10.17219/pim/139587

\section{Copyright}

(C) 2021 by Wroclaw Medical University

This is an article distributed under the terms of the

Creative Commons Attribution 3.0 Unported (CC BY 3.0)

(https://creativecommons.org/licenses/by/3.0/)

\begin{abstract}
Natural polymers have been commonly applied in medicine and pharmacy. Their primary function is to enhance drug delivery, tissue regeneration or wound healing, and diagnostics. Natural polymers appear promising for photodynamic protocols, including photodiagnosis (PDD) and photodynamic therapy (PDT). Currently, the most challenging issue with natural polymers is to appropriately select the most effective material regarding the type of cancer treated. The technological achievements enable functionalization of natural polymers by specific antibodies, or enhancement using fluorescent or quantum dot markers for diagnostic applications. This review will discuss the types and properties of natural polymers and available applications of PDD and PDT which seem to be promising in cancer treatment. Treatment of neoplastic diseases is still a challenge for both physicians and scientists, so the search for alternative methods of treatment and diagnosis based on natural materials is relevant.
\end{abstract}

Key words: photodynamic therapy, anticancer therapy, natural polymers, photodynamic diagnosis

\section{Streszczenie}

Naturalne polimery są powszechnie stosowane w medycynie i farmacji. Ich podstawowym zadaniem jest lepsze dostarczanie leków, regeneracja tkanek i gojenie ran oraz diagnostyka. Naturalne polimery są obiecujące w protokołach fotodynamicznych, w tym fotodiagnostyce (PDD) i terapii fotodynamicznej (PDT). Jednak największym wyzwaniem jest odpowiedni dobór optymalnego i skutecznego materiału pod kątem wybranego typu nowotworu. Osiągnięcia technologiczne umożliwiają funkcjonalizację naturalnych polimerów przez specyficzne przeciwciała lub wzmocnienie za pomocą znaczników fluorescencyjnych lub kropek kwantowych do zastosowań diagnostycznych. W niniejzzej pracy przeglądowej omówiono i podsumowano ostatnie dane dotyczące rodzajów i właściwości naturalnych polimerów oraz ich możliwe zastosowania w PDD i PDT, które wydają się obiecujące w leczeniu chorób nowotworowych. Leczenie chorób nowotworowych wciąż jest wyzwaniem zarówno dla lekarzy, jak i naukowców, zatem poszukiwanie alternatywnych metod leczenia i diagnozowania w oparciu o naturalne materiały jest wciąż aktualne.

Słowa kluczowe: terapia fotodynamiczna, diagnostyka fotodynamiczna, naturalne polimery, terapia przeciwnowotorowa 


\section{Introduction}

Cancer remains a worldwide health problem and is one of the pathologies with the most severe impact on global health. Despite advances in knowledge on recent technological improvements, the mechanisms of recurrence and metastasis, progression, and development of these cancers remain unclear. ${ }^{1,2}$ Current treatments such as surgery, chemo- and radiotherapy are not effective and have side effects. Photodynamic therapy (PDT) and diagnosis (PDD) are still promising and alternative treatment options for cancer. Early detection of cancer, particularly at a curable stage, is an essential factor to effectively reduce mortality rates. ${ }^{3}$ Unfortunately, conventional imaging technologies, including ultrasonography (US), computed tomography (CT) or magnetic resonance imaging (MRI), provide only anatomical and physiological information. ${ }^{4}$ Their limitations include a lack of possibility for distinction of malignancies from benign lesions. Moreover, nonspecific distribution throughout the body, fast metabolism and other side effects affecting individual's comfort need to be taken into consideration. Similar drawbacks are associated with conventional chemotherapy. Issues of drug resistance development and poor bioavailability need to be taken into account as well. ${ }^{5}$ Thus, PDT or PDD combined with natural polymers for the enhanced photosensitizing agent delivery may represent an excellent alternative therapy for controlling malignant diseases. This therapy is based on the photosensitizer (PS) molecule application, which is excited by the light in an established wavelength and, after excitation, can react with oxygen. This reaction generates reactive oxidant species (ROS) such as singlet oxygen, hydroxyl radical and hydrogen peroxide superoxide anion radical, leading to an oxidative imbalance in cells. The oxidant species attack many molecules in cells, including nucleic acid proteins, and lipids. The ROS cause severe changes in the physiological mechanism of signaling cascade or gene expression regulation and lead to cell death by apoptosis, necrosis or autophagy. The type of death depends on different conditions (PS, localization of PS, energy applied, and individual tumor resistance). ${ }^{6-8}$

The PDT involves the photosensitized oxidation of biomolecules which may undergo 2 mechanisms (type I and type II). Type I involves the light energy being transferred from excited molecules to biomolecules through electron/ hydrogen transfer. It is involved in the damage of specific biomolecules and the initiation of radical chain reactions. In type II, the excitation energy is transferred to molecular oxygen, leading to the formation of highly electrophilic singlet oxygen that directly causes damage to membranes, proteins and DNA. The consequence of PDT critically depends on the intracellular efficiency of the PS. The available PSs can be engaged in both PDT mechanisms with various activities. These activities can be divided into the following groups depending on their solubility: hydrophobic, hydrophilic and amphiphilic. ${ }^{9}$ However, in clinical practice, another classification into short-acting, intermediate-acting and long-acting PSs is utilized. ${ }^{10}$ The primary "weapon" of PDT against cancer is its ability to promote protein damage and membrane destruction; therefore, it is crucial to optimize the cytotoxic efficiency of this anticancer strategy. Furthermore, a higher degree of PS accumulation in cancer cells usually causes more cytotoxic effects. ${ }^{11,12}$ Free radicals and singlet oxygen formation provoke a secondary effect of lipid peroxidation, resulting in leakage out of the membrane. ${ }^{6}$ The PS is one of the 3 decisive elements of PDT, the other 2 being from light and oxygen. ${ }^{13}$ Because of their photochemical properties and uptake efficiency, only a few PSs have official approval for clinical application - mainly, porfimer sodium (Photofrin), mTHPC (Foscan), talaporfin sodium (NPe6, Laserphyrin), SnEt2 (Purlytin), veteprofin (Visudyne), and motexafin lutetium (LuTex). ${ }^{14,15}$ Numerous investigations have focused on a better characterization and development of PS with higher wavelengths, allowing for deeper penetration, a phenomenon known as the $2^{\text {nd }}$ generation of PSs. The $3^{\text {rd }}$ generation of PSs is the most effective in targeting cancer cells. These PSs are directed by antibodies or loaded in nanocarriers. ${ }^{16}$ The PDT can be involved in 3 crucial mechanisms of cancer tissue destruction. In the $1^{\text {st }}$ one, cancer cells are killed directly by the damaging action of ROS induced by PS excitations, leading to cell death through necrosis or apoptosis. ${ }^{8}$ Photodynamic therapy can also lead to indirect tumor destruction through damage of tumor vasculature, which obstructs the supply of oxygen, nutrients and vitamins, as well as to the activation of the immune system that stimulates inflammation and an immune response against tumor cells. ${ }^{9,17,18}$

The PDT may also be improved through connection with other anticancer therapies such as chemo- or radiotherapy and electropermeabilization of cancer cell membranes. ${ }^{19-21}$ Currently, PDT has been used to treat various cancers, such as skin, lung, bladder, breast, brain, ovarian, etc., in preclinical models and clinical investigations. Photodynamic reaction may also find use as a method of early cancer diagnosis, and as such is named photodynamic diagnosis (PDD). The PDD includes exciting and detecting tissue fluorescence from an earlier administered photosensitizing drug and illustrating diagnostic conclusions from the signals achieved. Finally, other non-cancer illnesses can also be treated by PDT, such as dermatological, mouth and cardiovascular diseases. ${ }^{22-24}$

\section{Types of polymeric materials}

Natural polymers, called biopolymers, are structures created in the life cycle of plants, fungi, bacteria, or animals. Most of the biopolymers found in nature are produced by a highly energy-efficient process termed molecular self-assembly. Overall, the driving forces of this process display structural compatibility through non-covalent, 
weak interactions and chemical complementarity. ${ }^{25,26}$ Biopolymers are assigned into the following groups: polypeptides, polysaccharides and polynucleotides. In particular, polysaccharide-based polymers exhibit high stability, biodegradability, biocompatibility, and a lack of toxicity. ${ }^{27}$ Different biopolymers such as pullulan, dextran, alginate, chitin, chitosan, albumin, hyaluronic acid (HA), gelatin, and guar gum are used for the creation of nanocarriers for drug delivery, especially in cancer drugs. ${ }^{28}$ It has been shown that some biopolymers have an anti-tumor effect themselves. ${ }^{27}$ For example, chitosan can induce membrane disruption in tumor cells and induce apoptosis. Biopolymers are also applied as a foundation to which drugs can be attached and delivered to targeted cells, which can result in less drug loss and lower toxicity for the whole organism. ${ }^{27}$ Moreover, proteins are used for drug delivery systems. For instance, collagen is used in ophthalmology as a component of the drugs delivery system - gelatin is easily cross-linkable and forms valuable hydrogels, and these are used to create matrices in tissue engineering. ${ }^{25}$ Likewise, albumin is used as a matrix in endovascular drug delivery systems. ${ }^{29}$

\section{Collagen}

In human tissues, the structural and biochemical support of cells is given by the external cellular matrix (ECM). The structure of the ECM is formed by a three-dimensional (3D) collagen scaffold to which adhesive glycoproteins and proteoglycans are attached. ${ }^{30}$ Collagen is an essential ECM component and one of the most beneficial scaffolding materials in tissue engineering. Apart from the fact that it is very well tolerated and biodegradable, its presence promotes the attachment and proliferation of the host cells. It also has good mechanical properties. ${ }^{27}$ Collagen proteins are made of triple helices which oligomerize into fibrils by self-assembly. Currently, 29 types of collagen have been identified, and differ based on the 3 chains that make up their triple helix. ${ }^{25}$ The most common type of collagen is collagen I, which can be found in tendons, skin and bones. Type II collagen dominates in intervertebral discs, cartilage and cornea. ${ }^{31}$

The sources of collagen type I for in vitro studies are bovine skin, bovine Achilles tendons and rat tails, while collagen type II is mainly obtained from articular cartilage. ${ }^{25}$ An alternative to obtaining collagen is its laboratory production using genetic engineering techniques developed by the Fibrogen company. ${ }^{32}$ Collagen obtained in this way is characterized by a defined composition and lower immunogenicity. The hierarchical organization of the collagen scaffold ensures excellent mechanical properties and supports cell adhesion. Its limitation is sensitivity to elevated temperature and gamma radiation. Despite the above limitations, collagen structures have found wide application in skin regeneration therapies. Collagen hydrogels that bind fibroblasts are a respectable substitute for the skin. By using different cross-linking collagen assemblies, it is possible to influence the tensile strength and biodegradability of the entire structure. Furthermore, these collagen hydrogels containing fibroblast cells are used to heal chronic wounds. Growth factors secreted by fibroblasts positively affect wound regeneration, while the collagen structure itself protects it against contamination. ${ }^{25}$ An example of a commercial collagen hydrogel dressing is Apligraf ${ }^{\circledR} .{ }^{33}$ Freeze-drying collagen solutions produce collagen sponges with pore diameters ranging from $50 \mu \mathrm{m}$ to $200 \mu \mathrm{m}$. Such structures can be enriched with other ECM structures like fibronectin or glycosaminoglycans. ${ }^{34}$ This modification improves the rate of cell adhesion and promotes their proliferation. These products are perfect for the treatment of extensive burn wounds. Other uses of collagen are nerve regeneration, tendon regeneration, bone regeneration, and intervertebral disc regeneration. ${ }^{25}$

\section{Elastin}

Elastin is another significant and important component of the ECM. It is a hydrophobic, fibrillar, structural protein found in connective tissue, and the main component of tendons, ligaments, lung tissue, and walls of larger blood vessels. Remarkably, tissues abundant in elastin are capable of regaining their original size and shape following stretching or compression. ${ }^{25}$ The elastin maturation process is called elastogenesis. Ripe elastin is a highly solid biopolymer, and its half-life is approx. 40 years. ${ }^{35}$ Its biomedical application concerns skin repair processes and the reconstruction of blood vessels. ${ }^{36}$ Elastin is often combined with collagen to create an environment with adequate mechanical strength, and to promote cell adhesion and proliferation. ${ }^{25}$ A technique for producing recombinant elastin has also been developed in a way that, depending on the temperature, can assume a disordered, fully hydrated or organized and cross-linked structure. These modified elastins are used in eye regeneration, bone regeneration or vascular grafting. ${ }^{37}$

\section{Silk}

Although the human body does not naturally produce silk, structures based on it are used in tissue engineering to regenerate liver tissues, bones, blood vessels, cartilage, ligaments, and cornea. The structure of silk shows exceptional mechanical properties, surpassing even synthetic materials. ${ }^{38}$ Natural silk fibers mainly consist of fibroin fibers stuck together with sericin. Fibroin is a protein from the scleroprotein group; its chains are mostly composed of glycine (about 40\%), alanine, serine, and tyrosine. Sericin (silk glue), in turn, is a protein that binds fibroin fibers together. It contains serine, glycine and aspartic acid residues. Silk is produced by various arthropods. Furthermore, the leading natural producer of this biopolymer is the mulberry silkworm Bombyx mori. ${ }^{39}$ Also noteworthy is the fact 
that in order to use silkworm-derived silk as a biomaterial, removal of sericin must be performed to ensure biocompatibility. Nevertheless, this negatively affects the biomaterial features. ${ }^{40}$ With the use of genetic engineering techniques, it is possible to create silk-based chimeric proteins with desirable properties on a large scale and with low variability of the obtained biopolymer. ${ }^{41}$ Various forms of silk-based biopolymers are currently produced, including hydrogels, fibers, foams, and meshes. Silk is also combined with other materials, such as elastin or peptides with antimicrobial properties, to increase its usefulness. Silk-based materials have also been shown to promote cell attachment, proliferation and differentiation of fibroblasts, osteoblasts, osteoclasts, and mesenchymal stem cells. ${ }^{39}$

\section{Marine biopolymers}

Marine organisms are a powerful source of highly functional polymer structures that create 3D scaffolds with high mechanical strength. ${ }^{25}$ These structures are increasingly used as scaffolds in tissue engineering. The main building materials of marine biopolymers are carbonate and calcium phosphate, but they also contain an admixture of an organic component in the form of proteins. Three types of collagen exist in sea sponges, along with human growth factor analogs. The main marine producers of biopolymers used in bone tissue engineering are corals, sea sponges, cuttlefish, and starfish. ${ }^{42}$ Finally, trace elements such as strontium, fluorine and magnesium present in the inorganic part of these structures are of key importance for the induction of bone mineralization. ${ }^{43}$

Marine organisms are also a rich reservoir of biopolymers used in the engineering of soft shells. These include $\mathrm{HA}$, alginate and chitosan. Hyaluronic acid is a high molecular weight water-soluble polysaccharide and it is mainly derived from the ECM of cartilaginous fish. It is a linear polymer composed of alternating 1-4-D-glucuronic and 1-3-N-acetyl-D-glucosamine residues. ${ }^{44}$ Hyaluronic acid exhibits viscoelastic properties, and because of this, is used to regenerate synovial fluid, treat rheumatoid arthritis and wounds, and to create skin substitutes. ${ }^{25}$ Modifications of HA are also used to reduce its solubility and slow its quick biodegradation. These modifications include esterification and combination with collagen, gelatin or chitosan. ${ }^{45}$

Alginate is a polysaccharide that builds the cell walls of brown algae. It consists of unbranched mannuronic and guluronic acid chains connected by glycosidic bonds. ${ }^{46}$ The main useful property of alginate is its gelling ability, which is why it is used to form wound dressings. Gelling of alginate helps absorb wound exudate and promote healing. ${ }^{47}$

Chitosan is a product of the deacetylation of chitin, a polymer that builds crustaceans. The structure of chitosan consists mainly of D-glucosamine (70-90\%) and $\mathrm{N}$-acetyl-D-glucosamine (10-30\%) chains that are linked by glycosidic bonds. Due to its antibacterial, moisturizing and hemostatic properties, chitosan is widely used in wound products. ${ }^{48}$

\section{Nanocarriers based on biopolymers}

Biopolymers are used to create systems for the effective and safe delivery of drugs to specific tissues. Using nanoencapsulation, it is possible to modulate the physicochemical and pharmacological properties of the transferred substances, ${ }^{49}$ increase the stability and bioavailability of drugs, while simultaneously reducing their side effects. ${ }^{50}$ The gelling and bioadhesive properties of biopolymers are used to form hydrogels to deliver anti-cancer compounds. The phenomenon of the sol-gel process, which is temperature-dependent, is exploited when administering the drug in a liquid form with the subsequent formation of a $3 \mathrm{D}$ matrix at the body temperature $\left(\mathrm{ca} .37^{\circ} \mathrm{C}\right)$. The adhesive properties promote the appropriate residence time of the drug in the matrix, which allows for avoiding the side effects of conventional systemic administration of therapeutics. Paclitaxel nanoformulation (PTX) with endogenous serum albumin is currently the first-line treatment in metastatic breast cancer, pancreatic cancer and advanced non-small cell lung cancer. ${ }^{49}$ This high-pressure homogenization procedure favors the reversible non-covalent albumin-PTX bonds and the formation of 130-nm nanoparticles (NPs). The drug accumulates more efficiently in solid tumors in this form due to the interaction between albumin particles and gp60 glycoprotein. ${ }^{51}$ Previously, Yoshioka et al. developed a hydrogel based on sodium alginate with an admixture of hydroxyapatite for the controlled release of the cytostatic. ${ }^{52}$ These hydrogel structures retain a high degree of structural integrity and release the bound drug at an appropriate rate. ${ }^{49}$ Furthermore, Ruel-Gariépy et al. have developed a chitosan-based hydrogel loaded with cytostatic, which was administered to the sites after tumor resection to inhibit its regrowth. The starting material was the patented formula of chitosan and $\beta$-glycerophosphate that undergoes a sol-gel transformation after reaching body temperature. ${ }^{53}$ This chitosanbased hydrogel is a promising strategy to avoid the drawbacks of systemic chemotherapy, providing relatively high local drug concentrations. Moreover, chitosan itself has a pro-apoptotic effect, inhibits the glycolytic pathway and modulates the activity of macrophages, leukocytes, and interleukin (IL)-1 and IL-2. ${ }^{53}$

Watanabe et al. have developed a HA nanoparticleloaded PTX that was embedded in a hydrogel based on collagen. Researchers observed that highly transducing breast cancer cells were very susceptible to the above hydrogel, which was explained by the release of cytostatic from nanostructures under the influence of metalloproteinases (MMPs) released by cancer. ${ }^{54}$ 
Biodegradability and non-toxicity are the essential features of innovative drug delivery systems. The use of gelling and adhesive properties of various polysaccharides and proteins to obtain a formulation using a local bioactive compound is a reasonable strategy to maximize the therapeutic effectiveness of different molecules. ${ }^{49}$

\section{Natural polymer-based delivery of photosensitizers}

Although numerous platforms exist for enhanced drug distribution, natural polymers seem to be promising in PS delivery. The main aim for PSs encapsulation is to improve the stability of hydrophobic PSs, protect the cargo and facilitate drug activity by longer release.,95,56 The other crucial issue is the enhanced permeability and retention (EPR) effect, where tumor vasculature is efficiently used in nanomedicine. However, in solid and low vascularized tumors, PSs delivery is still challenging. ${ }^{57,58}$ This problem can be solved with natural and biodegradable polymers, which are easily eliminated from the body. In the photodynamic procedures, polymeric nanocarriers were prepared from natural polymers, such as albumin, HA or chitosan. ${ }^{59}$ Wacker et al. used human serum albumin (HSA) as a drug carrier system for 5,10,15,20-tetrakis (m-hydroxyphenyl) porphyrine (mTHPP) and 5,10,15,20-tertrakis (m-hydroxyphenyl) chlorin (mTHPC). They examined the efficacy of these nanosystems against human leukemia cells. The previously performed study revealed that PSs were efficiently delivered and induced an increased singled oxygen generation in photodynamic protocols. ${ }^{60}$ In another study, bovine serum albumin (BSA) nanospheres were developed for the treatment of human esophageal carcinoma (Eca-109). These nanospheres synchronously encapsulated $\mathrm{Au}_{2} \mathrm{Se} / \mathrm{Au}$ core-shell nanostructures and significantly increased PS efficiency in cancer phototherapy. ${ }^{61}$ Portilho et al. also used BSA for nanosphere preparation and encapsulation of zinc-phthalocyanine tetrasulfonate $\left(\mathrm{ZnPcS}_{4}-\mathrm{AN}\right)$. Nanospheres were tested on in vivo model (Swiss albino mice) with breast cancer. That study indicated that nanosphere administration may inhibit tumor growth and necrotic cell death, with no side effects. ${ }^{62}$

The other type of polymers used in PDT is chitosanbased material. Chitosan is a biocompatible polysaccharide carrier that is an excellent material for producing highly biocompatible chlorin e6-loaded chitosan NPs. Ding et al. verified NPs in vitro and observed that PDT efficiency of Ce6-loaded CNPs considerably improved, in contrast to free Ce6, based on MTT and flow cytometry (FCM) assays. ${ }^{63}$ Kardumyan et al. chose a different approach; they used the presence of chitosan in a model reaction of tryptophan photo-oxidation. In their study, various porphyrins were used: disodium salt of 3,8-di (1-methoxyethyl) deuteroporphyrin IX, and sodium salts of chlorin e6, 5,10,15,20-tetraphenylporphyrin, and fluorinated tetraphenyl porphyrin-5,10,15,20-tetrakis (pentafluorophenyl) porphyrin. Physicochemical studies indicated that PSs in the presence of chitosan exhibited higher photocatalytic activity. In the case of PSs solubilized additionally in Pluronic F127, higher efficiency of singlet oxygen generation was observed. ${ }^{64}$

Chitosan NPs were also implemented for the early diagnosis of cancer. It was reported that MRI contrast agents loaded in chitosan nanosystems can be of use in cancer imaging. ${ }^{65}$ Further studies by Wang et al. documented the application of chitosan particles in photothermal therapy (PTT). Authors developed chitosan polymers with gold nanorods for stabilization, and these nanosystems demonstrated improved stability and biocompatibility in human colon HT-29 cancer cells. ${ }^{66}$ In other research, arachidyl chitosan (chitosan oligosaccharide-arachidic acid; CSOAA)-based self-assembled nanoprobes were used for cancer MRI imaging. Here, NPs were labeled with Cy5.5 and tested on head and neck cancer cell lines (Hep-2 and $\mathrm{FaDu}$ ). In comparison to the commercially applied contrast agents, these chitosan-based probes revealed better effects. ${ }^{67} \mathrm{Li}$ et al. showed that micelles based on the chitosan might be effective in PDT as well. Authors used Photosan as a photosensitive cargo for the in vitro therapy on human pancreatic cancer cells (Panc-1). The researchers discovered that Photosan-DA-Chitosan micelles demonstrated a strong photocytotoxic effect in their specific cell model, and provoked an increased release of ROS. ${ }^{68}$

Hyaluronic acid can also be used for nanoparticle creation. It is known that HA-based nanosystems are quickly captured by reticuloendothelial system (RES), ${ }^{59}$ which is a part of the immune system and includes phagocytic cells such as monocytes and macrophages. ${ }^{69}$ Currently, surface modification of HA with poly(ethylene glycol) (PEG) is the most encouraging method to lower RES uptake. ${ }^{59,69}$ Moreover, hyaluronan may affect tumorigenesis by converting an alternative energy source to glucose for malignant cells. ${ }^{70}$ Wang et al. used HA-based polymeric micelles for targeted delivery of protoporphyrin IX (PpIX) for photodynamic therapy toward human lung cancer cells (A549). ${ }^{71}$ In Table 1 below, a collection of the combinations of natural polymers and PSs used on in vitro and in vivo models is shown.

\section{Conjugated nanoparticles}

Nanoparticles, natural and synthetic, conjugated with targeting ligands of the representative cancer cells (e.g., antibodies, peptides, organic molecules) or anticancer drugs, which can be encapsulated by the NPs or attached directly, significantly enhancing the localization specificity and cytotoxic drug delivery, while minimizing toxicity. ${ }^{5,72,73}$ Furthermore, NPs can target other structures (e.g., vessels) and components of the cancer environment. ${ }^{74}$ They also enable detection of pathological changes at the molecular and cellular level in cellular processes 
Table 1. Natural polymers in photodynamic therapy (PDT) procedures in vitro and in vivo

\begin{tabular}{|c|c|c|}
\hline Type of nanocarrier & Photosensitizer & Model in vitro/in vivo \\
\hline Chitosan nanoparticles ${ }^{62}$ & chlorin e6 & $\begin{array}{c}\text { human lung } \\
\text { adenocarcinoma (A549) and human liver cell } \\
(\text { LO2) }\end{array}$ \\
\hline HSA as a drug carrier system ${ }^{59}$ & $\begin{array}{l}\text { for 5,10,15,20-tetrakis (m-hydroxyphenyl) } \\
\text { porphyrine (mTHPP) and 5,10,15,20-tertrakis } \\
\text { (m-hydroxyphenyl) chlorin (mTHPC) }\end{array}$ & $\begin{array}{l}\text { human leukemia cells } \\
\text { (Jurkat) }\end{array}$ \\
\hline BSA-nanospheres ${ }^{61}$ & $\begin{array}{l}\text { zinc-phthalocyanine tetrasulfonate }\left(\mathrm{ZnPCS}_{4^{-}}\right. \\
\text {AN) }\end{array}$ & Swiss albino mice with breast cancer \\
\hline $\mathrm{BSA}$ - nanospheres with $\mathrm{Au}_{2} \mathrm{Se} / \mathrm{Au}$ core-shell ${ }^{60}$ & zinc phthalocyanine (ZnPc) & human esophageal carcinoma (Eca-109) \\
\hline $\begin{array}{l}\text { Arachidyl chitosan (chitosan oligosaccharide-arachidic } \\
\text { acid; CSOAA)-based self-assembled nanoprobes }{ }^{66}\end{array}$ & Cy5.5 & $\begin{array}{l}\text { head and neck cancer cell lines (Hep-2 and } \\
\text { FaDu cells) }\end{array}$ \\
\hline $\begin{array}{l}\text { Amphiphilic chitosan derivative (photosan-DA-Chit) } \\
\text { micelles }^{67}\end{array}$ & photosan & human pancreatic cancer cells (Panc-1 cells) \\
\hline $\begin{array}{l}\text { Hyaluronic acid-b-poly (d,I-lactide-co-glycolide) } \\
\text { copolymer (HA-b-PLGA micelles) }\end{array}$ & protoporphyrin IX (PpIX) & human lung cancer (A549 cells) \\
\hline
\end{tabular}

HSA - human serum albumin; BSA - bovine serum albumin.

of the living cell without disturbing them; e.g., genetic mutations, protein overexpression or dysregulation, and cancer cells proliferation and metabolism. Moreover, Chen et al. emphasized the revolutionizing importance of theragnostic NPs for the future of treatment management. ${ }^{16}$ This multifunctional system is based on $1 \mathrm{NP}$ simultaneously linked with diagnostic agents and therapeutic compounds. The solution enables the use of targeted therapy while monitoring its progress. According to these advantages, the use of ligand-conjugated NPs in molecular imaging or as a drug delivery system indicates that the method may represent a promising solution in cancer therapy and diagnosis.

Basing the production of these NPs on natural polymers ensures high biocompatibility, biodegradability, non-toxicity, and lack of immunogenicity. ${ }^{5}$ Additionally, the presence of specific protein binding sites and functional groups on their surface can improve target transport or tissue engineering protocols for efficient binding with therapeutic compounds or characteristic ligands. ${ }^{75,76}$

Among the NPs widely used in biomedical imaging, there are silver (AgNPs) and gold NPs (AuNPs), quantum dots conjugated NPs, and iron oxide NPs (ION). Recently, natural cellulosic polymers have found use in the formulation of silver NPs (AgNPs). ${ }^{77,78}$ A few methods of AgNPs synthesis exist, including biological, chemical and physical. Unfortunately, each of them is limited by several factors, such as solvent contamination, toxic reducing agents or particle aggregation. Abdellatif et al. investigated methylcellulose (MC), hydroxypropyl methylcellulose (HPMC) and ethylcellulose (EC). ${ }^{77}$ The obtained results showed that cellulosic polymers might act as an efficient reducing agent for AgNPs production. The AgNPs based on natural polymers exhibited no aggregation and the MC, HPMC and EC negative charge enhanced NP stability. Recently, Zhou et al. reviewed the use of natural polymers, such as chitosan, lignin, cellulose, and sugarcane bagasse pulp in the production of carbon dots (CDs). ${ }^{79}$ They appeared as high-potential green replacements for conventional high-potential quantum dots (QDs) due to improved biocompatibility and great photoluminescence (PL).

The available literature sources report an extensive analysis of ligand-conjugated NPs based on natural polymers, and present promising candidates to improve cancer therapy with reduced toxicity. Among them we can distinguish: chitosan-based NPs loaded with doxorubicin $(\mathrm{DOX})^{78,80}$ and curcumin ${ }^{81}$; alginate-based NPs loaded with docetaxel (DXL), ${ }^{82}$ paclitaxel (PXL) ${ }^{83}$ or $\mathrm{DOX}^{84}$; and dextran-based NPs loaded with DOX. ${ }^{85,86}$ Moreover, NPs used to increase stability or improve delivery and uptake of microRNAs and siRNAs by tumor cells are currently in the spotlight. ${ }^{87-89}$

\section{Conclusions}

In conclusion, this review serves as a summary of the application of natural polymers in nanocarriers for drug delivery. Natural materials used in nanosystems are favorable because of biodegradability, limited side effects and improved bioavailability. In PDT, the usability of nanosystems based on natural polymers can solve one of the problems which involves restrictions in application of various PSs because of their low water solubility. The latest nanotechnology research demonstrates the high potency in surface functionalization, which aims to selectively detect and destroy cancerous tissues. Thus, natural polymers in anticancer therapies appear to be suitable and promising for clinical applications.

\section{ORCID iDs}

Julita Kulbacka (D) https://orcid.org/0000-0001-8272-5440 Anna Choromańska (D) https://orcid.org/0000-0001-9997-7783 Zofia Łapińska (D) https://orcid.org/0000-0001-5070-2746 Jolanta Saczko (D) https://orcid.org/0000-0001-5273-5293 


\section{References}

1. Minn AJ, Gupta GP, Siegel PM, et al. Genes that mediate breast cancer metastasis to lung. Nature. 2005;436(7050):518-524. doi:10.1038/ nature03799

2. Weigelt B, Peterse J, van 't Veer L. Breast cancer metastasis: Mark ers and models. Nat Rev Cancer. 2005;5(8):591-602. doi:10.1038/ NRC1670

3. Chen X, Zhou H, Li X, et al. Plectin-1 targeted dual-modality nanoparticles for pancreatic cancer imaging. EBioMedicine. 2018;30:129-137. doi:10.1016/j.ebiom.2018.03.008

4. Ma YY, Jin KT, Wang SB, et al. Molecular imaging of cancer with nanoparticle-based theranostic probes. Contrast Media Mol Imaging. 2017;2017:1026270. doi:10.1155/2017/1026270

5. Wong KH, Lu A, Chen X, Yang Z. Natural ingredient-based polymeric nanoparticles for cancer treatment. Molecules. 2020;25(16):3620. doi:10.3390/molecules25163620

6. Bacellar IOL, Tsubone TM, Pavani C, Baptista MS. Photodynamic efficiency: From molecular photochemistry to cell death. Int J Mol Sci. 2015;16(9):20523-20559. doi:10.3390/ijms160920523

7. Tsubone TM, Martins WK, Pavani C, Junqueira HC, Itri R, Baptista MS Enhanced efficiency of cell death by lysosome-specific photodamage. Sci Rep. 2017;7(1):1-19. doi:10.1038/s41598-017-06788-7

8. Galluzzi L, Vitale I, Aaronson SA, et al. Molecular mechanisms of cell death: Recommendations of the Nomenclature Committee on Cell Death 2018. Cell Death Differ. 2018;25(3):486-541. doi:10.1038/s41418 017-0012-4

9. Kwiatkowski S, Knap B, Przystupski D, et al. Photodynamic therapy: Mechanisms, photosensitizers and combinations. Biomed Pharmacother 2018;106:1098-1107. doi:10.1016/j.biopha.2018.07.049

10. Niculescu AG, Grumezescu AM. Photodynamic therapy: An up-todate review. App/Sci. 2021;11(8):3626. doi:10.3390/app11083626

11. Jensen TJ, Vicente MGH, Luguya R, Norton J, Fronczek FR, Smith KM. Effect of overall charge and charge distribution on cellular uptake, distribution and phototoxicity of cationic porphyrins in HEp2 cells. J Photochem Photobiol B Biol. 2010;100(2):100-111. doi:10.1016/j.jphotobiol.2010.05.007

12. Pavani C, lamamoto $Y$, Baptista MS. Mechanism and efficiency of cell death of type II photosensitizers: Effect of zinc chelation. Photochem Photobiol. 2012;88:774-781. doi:10.1111/j.1751-1097.2012.01102.x

13. Feng $X$, Shi $Y$, Xie L, et al. Synthesis, characterization, and biological evaluation of a porphyrin-based photosensitizer and its isomer for effective photodynamic therapy against breast cancer. JMed Chem. 2018;61(16):7189-7201. doi:10.1021/acs.jmedchem.8b00547

14. Anand S, Ortel BJ, Pereira SP, Hasan T, Maytin EV. Biomodulatory approaches to photodynamic therapy for solid tumors. Cancer Lett. 2012;326(1):8-16. doi:10.1016/j.canlet.2012.07.026

15. Banerjee SM, MacRobert AJ, Mosse CA, Periera B, Bown SG, Keshtgar MRS. Photodynamic therapy: Inception to application in breast cancer. Breast. 2017;31:105-113. doi:10.1016/j.breast.2016.09.016

16. Chen F, Ehlerding EB, Cai W. Theranostic nanoparticles. J Nucl Med. 2014;55(12):1919-1922. doi:10.2967/jnumed.114.146019

17. Spring BQ, Rizvi I, Xu N, Hasan T. The role of photodynamic therapy in overcoming cancer drug resistance. Photochem Photobiol Sci. 2015;14(8):1476-1491. doi:10.1039/c4pp00495g

18. van Straten D, Mashayekhi V, de Bruijn HS, Oliveira S, Robinson DJ. Oncologic photodynamic therapy: Basic principles, current clinical status and future directions. Cancers (Basel). 2017;9(2):19. doi:10.3390/ cancers9020019

19. Weżgowiec J, Kulbacka J, Saczko J, Rossowska J, Chodaczek G, Kotulska M. Biological effects in photodynamic treatment combined with electropermeabilization in wild and drug resistant breast cancer cells. Bioelectrochemistry. 2018;123:9-18. doi:10.1016/j.bioelechem. 2018.04.008

20. Zimmermann A, Walt $H$, Haller $U$, Baas $P$, Klein SD. Effects of chlorinmediated photodynamic therapy combined with fluoropyrimidines in vitro and in a patient. Cancer Chemother Pharmacol. 2003;51(2): 147-154. doi:10.1007/s00280-002-0549-9

21. Crescenzi E, Varriale L, lovino M, Chiaviello A, Veneziani BM, Palumbo G. Photodynamic therapy with indocyanine green complements and enhances low-dose cisplatin cytotoxicity in MCF-7 breast cancer cells. Mol Cancer Ther. 2004;3(5):537-544. PMID:15141011
22. Babilas P, Karrer S, Sidoroff A, Landthaler M, Szeimies RM. Photodynamic therapy in dermatology: An update. Photodermatol Photoimmunol Photomed. 2005;21(3):142-149. doi:10.1111/j.1600-0781.2005.00147.x

23. Kossodo S, LaMuraglia GM. Clinical potential of photodynamic therapy in cardiovascular disorders. Am J Cardiovasc Drugs. 2001;1(1):15-21. doi:10.2165/00129784-200101010-00002

24. Prazmo EJ, Kwaśny M, Łapiński M, Mielczarek A. Photodynamic therapy as a promising method used in the treatment of oral diseases. Adv Clin Exp Med. 2016;25(4):799-807. doi:10.17219/acem/32488

25. Bassas-Galia M, Follonier S, Pusnik M, Zinn M. Natural polymers: A source of inspiration. In: Perale G, Hilborn J. Bioresorbable Polymers for Biomedical Applications: From Fundamentals to Translational Medicine. Sawston, UK: Woodhead Publishing; 2017:31-64. doi:10.1016/B9780-08-100262-9.00002-1

26. Zhao X, Zhang S. Fabrication of molecular materials using peptide construction motifs. Trends Biotechnol. 2004;22(9):470-476. doi:10. 1016/j.tibtech.2004.07.011

27. Khan MJ, Svedberg A, Singh AA, Ansari MS, Karim Z. Use of nanostructured polymer in the delivery of drugs for cancer therapy. In: Swain SK, Jawaid M. Nanostructured Polymer Composites for Biomedical Applications. Amsterdam, the Netherlands: Elsevier; 2019:261-276. doi:10.1016/b978-0-12-816771-7.00013-2

28. Coviello T, Matricardi P, Marianecci C, Alhaique F. Polysaccharide hydrogels for modified release formulations. J Control Release. 2007; 119(1):5-24. doi:10.1016/j.jconrel.2007.01.004

29. Merodio M, Irache JM, Valamanesh F, Mirshahi M. Ocular disposition and tolerance of ganciclovir-loaded albumin nanoparticles after intravitreal injection in rats. Biomaterials. 2002;23(7):1587-1594. doi:10.1016/S0142-9612(01)00284-8

30. Bosman FT, Stamenkovic I. Functional structure and composition of the extracellular matrix. J Pathol. 2003;200(4):423-428. doi:10.1002/ path.1437

31. Parenteau-Bareil R, Gauvin R, Berthod F. Collagen-based biomaterials for tissue engineering applications. Materials (Basel). 2010;3(3): 1863-1887. doi:10.3390/ma3031863

32. Yang C, Hillas PJ, Báez JA, et al. The application of recombinant human collagen in tissue engineering. BioDrugs. 2004;18(2):103-119. doi:10. 2165/00063030-200418020-00004

33. Karr J. Utilization of living bilayered cell therapy (Apligraf) for heel ulcers. Adv Skin Wound Care. 2008;21(6):270-274. doi:10.1097/01.asw. 0000323504.68401.d6

34. Doillon CJ, Silver FH. Collagen-based wound dressing: Effects of hyaluronic acid and firponectin on wound healing. Biomaterials. 1986; 7(1):3-8. doi:10.1016/0142-9612(86)90080-3

35. Stitzel J, Liu J, Lee SJ, et al. Controlled fabrication of a biological vascular substitute. Biomaterials. 2006;27(7):1088-1094. doi:10.1016/j. biomaterials.2005.07.048

36. Wang E, Lee SH, Lee SW. Elastin-like polypeptide based hydroxyapatite bionanocomposites. Biomacromolecules. 2011;12(3):672-680. doi:10.1021/bm101322m

37. Gotoh Y, Ishizuka Y, Matsuura T, Niimi S. Spheroid formation and expression of liver-specific functions of human hepatocellular carcinoma-derived FLC-4 cells cultured in lactose/silk fibroin conjugate sponges. Biomacromolecules. 2011;12(5):1532-1539. doi:10.1021/ bm101495c

38. Altman GH, Diaz F, Jakuba C, et al. Silk-based biomaterials. Biomaterials. 2003;24(3):401-416. doi:10.1016/S0142-9612(02)00353-8

39. Liu H, Ge Z, Wang Y, Toh SL, Sutthikhum V, Goh JCH. Modification of sericin-free silk fibers for ligament tissue engineering application. J Biomed Mater Res B App/ Biomater. 2007;82(1):129-138. doi:10.1002/ jbm.b.30714

40. Green DW, Padula MP, Santos J, Chou J, Milthorpe B, Ben-Nissan B. A therapeutic potential for marine skeletal proteins in bone regeneration. Mar Drugs. 2013;11(4):1203-1220. doi:10.3390/md11041203

41. Vago R, Plotquin D, Bunin A, Sinelnikov I, Atar D, Itzhak D. Hard tissue remodeling using biofabricated coralline biomaterials. J Biochem Biophys Methods. 2002;50(2-3):253-259. doi:10.1016/S0165-022X(01) 00235-4

42. Bonnelye $E$, Chabadel A, Saltel F, Jurdic P. Dual effect of strontium ranelate: Stimulation of osteoblast differentiation and inhibition of osteoclast formation and resorption in vitro. Bone. 2008;42(1): 129-138. doi:10.1016/j.bone.2007.08.043 
43. Liu H, Mao J, Yao K, Yang G, Cui L, Cao Y. A study on a chitosan-gelatin-hyaluronic acid scaffold as artificial skin in vitro and its tissue engineering applications. J Biomater Sci Polym Ed. 2004;15(1):25-40. doi:10.1163/156856204322752219

44. Rinaudo M. Main properties and current applications of some polysaccharides as biomaterials. Polym Int. 2008;57(3):397-430. doi:10. 1002/pi.2378

45. Wiegand C, Hipler UC. Polymer-based biomaterials as dressings for chronic stagnating wounds. In: Macromolecular Symposia. Vol. 294. Hoboken, USA: John Wiley \& Sons, Ltd; 2010:1-13. doi:10.1002/masy. 200900028

46. Ravi Kumar MNV. A review of chitin and chitosan applications. React Funct Polym. 2000;46(1):1-27. doi:10.1016/S1381-5148(00)00038-9

47. Dai T, Tanaka M, Huang YY, Hamblin MR. Chitosan preparations for wounds and burns: Antimicrobial and wound-healing effects. Expert Rev Anti Infect Ther. 2011;9(7):857-879. doi:10.1586/eri.11.59

48. Chenthamara D, Subramaniam S, Ramakrishnan SG, et al. Therapeutic efficacy of nanoparticles and routes of administration. Biomater Res. 2019;23(1):1-29. doi:10.1186/s40824-019-0166-x

49. Voci S, Gagliardi A, Molinaro R, Fresta M, Cosco D. Recent advances of taxol-loaded biocompatible nanocarriers embedded in natural polymer-based hydrogels. Gels. 2021;7(2):33. doi:10.3390/gels7020033

50. Gagliardi A, Giuliano E, Venkateswararao E, et al. Biodegradable polymeric nanoparticles for drug delivery to solid tumors. Front Pharmacol. 2021;12:17. doi:10.3389/fphar.2021.601626

51. Parodi A, Miao J, Soond SM, Rudzińska M, Zamyatnin AA. Albumin nanovectors in cancer therapy and imaging. Biomolecules. 2019;9(6):218. doi:10.3390/biom9060218

52. Yoshioka T, Ikoma T, Monkawa A, et al. Preparation of hydroxyapatite-alginate gels as a carrier for controlled release of paclitaxel. Key Eng Mater. 2007;330-332:1053-1056. doi:10.4028/www.scientific. net/kem.330-332.1053

53. Ruel-Gariépy E, Shive M, Bichara A, et al. A thermosensitive chitosan-based hydrogel for the local delivery of paclitaxel. Eur J Pharm Biopharm. 2004;57(1):53-63. doi:10.1016/S0939-6411(03)00095-X

54. Watanabe K, Nishio Y, Makiura R, Nakahira A, Kojima C. Paclitaxelloaded hydroxyapatite/collagen hybrid gels as drug delivery systems for metastatic cancer cells. Int J Pharm. 2013;446(1-2):81-86 doi:10.1016/j.ijpharm.2013.02.002

55. Zhang Y, Wang B, Zhao R, Zhang Q, Kong X. Multifunctional nanoparticles as photosensitizer delivery carriers for enhanced photodynamic cancer therapy. Mater Sci Eng C. 2020;115:111099. doi:10.1016/j. msec.2020.111099

56. Huang YY, Sharma SK, Dai T, et al. Can nanotechnology potentiate photodynamic therapy? Nanotechnol Rev. 2012;1(2):111-146. doi:10. 1515/ntrev-2011-0005

57. Maeda H, Tsukigawa K, Fang J. A retrospective 30 years after discovery of the enhanced permeability and retention effect of solid tumors: Next-generation chemotherapeutics and photodynamic therapy. Problems, solutions and prospects. Microcirculation. 2016; 23(3):173-182. doi:10.1111/micc.12228

58. Gao W, Wang Z, Lv L, et al. Photodynamic therapy induced enhancement of tumor vasculature permeability using an upconversion nanoconstruct for improved intratumoral nanoparticle delivery in deep tissues. Theranostics. 2016;6(8):1131-1144. doi:10.7150/thno.15262

59. Debele TA, Peng S, Tsai HC. Drug carrier for photodynamic cancer therapy. Int J Mol Sci. 2015;16(9):22094-22136. doi:10.3390/ijms160922094

60. Wacker M, Chen K, Preuss A, Possemeyer K, Roeder B, Langer K. Photosensitizer loaded HSA nanoparticles. I: Preparation and photophysical properties. Int J Pharm. 2010;393(1-2):254-263. doi:10.1016/j. ijpharm.2010.04.022

61. Yu C, Wo F, Shao Y, Dai X, Chu M. Bovine serum albumin nanospheres synchronously encapsulating gold selenium/gold nanoparticles and photosensitizer for high-efficiency cancer phototherapy. ApplBiochem Biotechnol. 2013;169(5):1566-1578. doi:10.1007/s12010-012-0078-X

62. Portilho FA, De Oliveira Cavalcanti CE, Miranda-Vilela AL, et al. Antitumor activity of photodynamic therapy performed with nanospheres containing zinc-phthalocyanine. J Nanobiotechnology. 2013;11:41. doi:10.1186/1477-3155-11-41

63. Ding YF, Li S, Liang L, et al. Highly biocompatible chlorin e6-loaded chitosan nanoparticles for improved photodynamic cancer therapy. ACS Appl Mater Interfaces. 2018;10(12):9980-9987. doi:10.1021/ acsami.8b01522
64. Kardumyan VV, Aksenova NA, Timofeeva VA, et al. Effect of chitosan on the activity of water-soluble and hydrophobic porphyrin photosensitizers solubilized by amphiphilic polymers. Polymers (Basel). 2021;13(7):1007. doi:10.3390/polym13071007

65. Key J, Park K. Multicomponent, tumor-homing chitosan nanoparticles for cancer imaging and therapy. Int J Mol Sci. 2017;18(3):594. doi:10.3390/ijms18030594

66. Wang $\mathrm{CH}$, Chang CW, Peng CA. Gold nanorod stabilized by thiolated chitosan as photothermal absorber for cancer cell treatment. JNanoparticle Res. 2011;13(7):2749-2758. doi:10.1007/s11051-010-0162-5

67. Termsarasab U, Cho HJ, Moon HT, Park JH, Yoon IS, Kim DD. Selfassembled magnetic resonance imaging nanoprobes based on arachidyl chitosan for cancer diagnosis. Colloids Surfaces B Biointerfaces. 2013;109:280-286. doi:10.1016/j.colsurfb.2013.03.058

68. Li H, Yu Z, Wang S, et al. Photosensitizer-encapsulated amphiphilic chitosan derivative micelles: Photoactivity and enhancement of phototoxicity against human pancreatic cancer cells. J Photochem Photobiol B Biol. 2015;142:212-219. doi:10.1016/j.jphotobiol.2014.10.020

69. Misra S, Heldin P, Hascall VC, et al. Hyaluronan-CD44 interactions as potential targets for cancer therapy. FEBS J. 2011;278(9):1429-1443. doi:10.1111/j.1742-4658.2011.08071.x

70. Smedsrød B, Seljelid R. Fate of intravenously injected aminated $\beta(1 \rightarrow 3)$ polyglucose derivatized with 125I-tyraminyl cellobiose. Immunopharmacology. 1991;21(3):149-158. doi:10.1016/0162-3109(91)90020-Y

71. Wang X, Wang J, Li J, Huang H, Sun X, Lv Y. Development and evaluation of hyaluronic acid-based polymeric micelles for targeted delivery of photosensitizer for photodynamic therapy in vitro. J Drug Deliv Sci Technol. 2018;48:414-421. doi:10.1016/j.jddst.2018.10.018

72. Błaszczak-ŚwiątkiewiczK, Olszewska P, Mikiciuk-OlasikE. Zastosowanie nanocząsteczek w leczeniu i diagnostyce nowotworów. Nowotwory. 2013;63(4):320-330. doi:10.5603/NJO.2013.0020

73. Shivani S, Ravindranath S. Nanoparticle in pharmaceutical drug delivery system: A review. J Drug Deliv Ther. 2019;9(3):543-548.

74. Shin SJ, Beech JR, Kelly KA. Targeted nanoparticles in imaging: Paving the way for personalized medicine in the battle against cancer. Integr Biol (Camb). 2013;5(1):29-42. doi:10.1039/c2ib20047c

75. Ulbrich K, Holá K, Šubr V, Bakandritsos A, Tuček J, Zbořil R. Targeted drug delivery with polymers and magnetic nanoparticles: Covalent and noncovalent approaches, release control, and clinical studies. Chem Rev. 2016;116(9):5338-5431. doi:10.1021/acs.chemrev.5b00589

76. Ige OO, Umoru LE, Aribo S. Natural products: A minefield of biomaterials. ISRN Mater Sci. 2012;2012:1-20. doi:10.5402/2012/983062

77. Abdellatif AAH, Alturki HNH, Tawfeek HM. Different cellulosic polymers for synthesizing silver nanoparticles with antioxidant and antibacterial activities. Sci Rep. 2021;11(1):84. doi:10.1038/s41598-020-79834-6

78. Niu S, Williams GR, Wu J, et al. A chitosan-based cascade-responsive drug delivery system for triple-negative breast cancer therapy. J Nanobiotechnology. 2019;17(1):95. doi:10.1186/s12951-019-0529-4

79. Zhou Y, Sharma SK, Peng Z, Leblanc RM. Polymers in carbon dots: A review. Polymers (Basel). 2017;9(2):67. doi:10.3390/polym9020067

80. Tian Q, Zhang CN, Wang XH, et al. Glycyrrhetinic acid-modified chitosan/poly(ethylene glycol) nanoparticles for liver-targeted delivery. Biomaterials. 2010;31(17):4748-4756. doi:10.1016/j.biomaterials.2010. 02.042

81. Esfandiarpour-Boroujeni S, Bagheri-Khoulenjani S, Mirzadeh $\mathrm{H}$, Amanpour S. Fabrication and study of curcumin loaded nanoparticles based on folate-chitosan for breast cancer therapy application. Carbohydr Polym. 2017;168:14-21. doi:10.1016/j.carbpol.2017.03.031

82. Chiu HI, Ayub AD, Mat Yusuf SNA, Yahaya N, Abbd Kadir E, Lim V. Docetaxel-loaded disulfide cross-linked nanoparticles derived from thiolated sodium alginate for colon cancer drug delivery. Pharmaceutics. 2020;12(1):38. doi:10.3390/pharmaceutics12010038

83. Ayub AD, Chiu HI, Mat Yusuf SNA, Abd Kadir E, Ngalim SH, Lim V. Biocompatible disulphide cross-linked sodium alginate derivative nanoparticles for oral colon-targeted drug delivery. Artif Cells Nanomed Biotechnol. 2019;47(1):353-369. doi:10.1080/21691401.2018.1557672

84. Gao C, Tang F, Zhang J, Lee SMY, Wang R. Glutathione-responsive nanoparticles based on a sodium alginate derivative for selective release of doxorubicin in tumor cells. J Mater Chem B. 2017;5(12):2337-2346. doi:10.1039/c6tb03032g

85. Tang Y, Li Y, Xu R, et al. Self-assembly of folic acid dextran conjugates for cancer chemotherapy. Nanoscale. 2018;10(36):17265-17274. doi:10.1039/c8nr04657c 
86. Thambi T, You DG, Han HS, et al. Bioreducible carboxymethyl dextran nanoparticles for tumor-targeted drug delivery. Adv Healthc Mater. 2014;3(11):1829-1838. doi:10.1002/adhm.201300691

87. Foerster F, Bamberger D, Schupp J, et al. Dextran-based therapeutic nanoparticles for hepatic drug delivery. Nanomedicine (Lond). 2016;11(20):2663-2677. doi:10.2217/nnm-2016-0156
88. Nascimento AV, Singh A, Bousbaa H, Ferreira D, Sarmento B, Amiji MM. Mad2 checkpoint gene silencing using epidermal growth factor receptor-targeted chitosan nanoparticles in non-small cell lung cancer model. Mol Pharm. 2014;11(10):3515-3527. doi:10.1021/mp5002894

89. Zhang L, lyer AK, Yang $X$, et al. Polymeric nanoparticle-based delivery of microRNA-199a-3p inhibits proliferation and growth of osteosarcoma cells. Int J Nanomedicine. 2015;10(1):2913-2924. doi:10.2147/ IJN.S79143 